\title{
The Technology of Precise Application of Herbicides in Onion Field Cultivation
}

\author{
Piotr Rybacki ${ }^{1}$, Przemysław Przygodziński ${ }^{1}$, Andrzej Osuch ${ }^{2, *}{ }^{\circledR}$, Andrzej Blecharczyk ${ }^{1}\left(\mathbb{D}\right.$, Ryszard Walkowiak $^{2}$, \\ Ewa Osuch ${ }^{2}$ (D) and Ireneusz Kowalik ${ }^{1}$ (D)
}

1 Department of Agronomy, Poznań University of Life Sciences, 11 Dojazd St., 60-632 Poznań, Poland; piotr.rybacki@up.poznan.pl (P.R.); p.przygodzinski@interia.pl (P.P.); andrzej.blecharczyk@up.poznan.pl (A.B.); ireneusz.kowalik@up.poznan.pl (I.K.)

2 Department of Biosystems Engineering, Poznań University of Life Sciences, 50 Wojska Polskiego St., 60-637 Poznań, Poland; ewa.osuch@up.poznan.pl (E.O.)

* Correspondence: andrzej.osuch@up.poznan.pl

Citation: Rybacki, P.; Przygodziński, P.; Osuch, A.; Blecharczyk, A.; Walkowiak, R.; Osuch, E.; Kowalik, I. The Technology of Precise Application of Herbicides in Onion Field Cultivation. Agriculture 2021, 11, 577. https://doi.org/

10.3390/agriculture11070577

Received: 13 May 2021

Accepted: 21 June 2021

Published: 24 June 2021

Publisher's Note: MDPI stays neutral with regard to jurisdictional claims in published maps and institutional affiliations.

Copyright: () 2021 by the authors. Licensee MDPI, Basel, Switzerland. This article is an open access article distributed under the terms and conditions of the Creative Commons Attribution (CC BY) license (https:// creativecommons.org/licenses/by/ $4.0 /)$.

\begin{abstract}
The purpose of the field experiments was to show possible differences in the quality and size of onion yield and the amount of working liquid used in the technology of the precise application of herbicides. The research material was an onion plantation during three growing seasons in 2015/2016, 2016/2017, and 2017/2018. Cultivation conditions were the same for all plots covered by the experiment. Onions were grown in the row-strip method with a spacing of $150 \mathrm{~cm}$. The experimental factor was the method of weed control on the plots: A-without weeding (control); $\mathrm{B}$ - manual weeding; $\mathrm{C}$-conventional herbicide application; $\mathrm{D}$-precise herbicide application. Herbicides were used: Agil 100EC, Pendigan 330EC, Roundup 360SL, Galigan 240EC, Goal 480SC, Lontrel 300SL, Emblem 20WP, Fusilade Forte 150EC, Szogun 10EC, and Lentagran 45WP. The total onion yield did not differ statistically within the accepted confidence interval, regardless of the weeding method in the growing seasons studied. The developed technology allows a reduction in herbicide consumption in onion cultivation by $26 \%$ compared to conventional technology, which is of great importance in the aspect of introducing chemical substances into the environment and their accumulation in crops.
\end{abstract}

Keywords: strip spraying; weed control; chemical protection; phytotoxicity

\section{Introduction}

The need to reduce the harmful compounds in agricultural products forces a reduction in the amount of pesticides used in field cultivation [1,2]. A solution to this problem may be strip spraying technology and the precise application of working liquid, which, as many researchers claim, also allows for savings in the amount of chemical compounds used [3,4]. Main et al. [5], in carrot cultivation, showed that the strip spraying of rows $30 \mathrm{~cm}$ wide, with the addition of weeding by other methods, allowed herbicide to be saved by $66 \%$. Oliver et al. [6], in research carried out in the cultivation of sugar cane, showed that strip application of the herbicide allowed for a $60 \%$ saving of the substances used to destroy weeds, and in the case of cultivation on elevated ridges, this allowed a reduction in the amount of active substances in the water in the drainage system. Similar results were obtained by Ivany [7] in an experiment in potato cultivation, where the herbicide was applied in rows $30 \mathrm{~cm}$ wide, and weeds were destroyed within rows using mechanical hoes. Despite the presence of individual weeds in this method of controlling them, the amount of yield did not differ compared to the conventional method.

In the case of the chemical method of reducing weed infestation, the row zone is often sprayed with selected herbicides, while the inter-row zone is sprayed with cheaper nonselective ones. However, the use of non-selective herbicides requires a different approach in terms of the application method and the use of crop protection shields. Such research was 
carried out by Collins et al. [8] in lupin cultivation, confirming the effectiveness of spraying with herbicide shields. The experiments carried out by [9] in the cultivation of sugar beet with the use of a high-precision positioning system (RTK-GPS) showed that strip spraying with selective herbicide shields in rows and non-selective ones in the inter-rows allowed a reduction in the average manual weeding time by $53 \%$ and the use of selective herbicides by $76 \%$. The use of this experimental technology has allowed, according to Carballido et al. [10], savings of 54 EUR.ha ${ }^{-1}$ and optimized sugar beet production in terms of weed control technology. Savings due to the application of pesticides of about $50 \%$ when using the above weed control method with the use of an automatic steering system with high accuracy were also confirmed in the research by Perez-Ruiz et al. [11]. Similarly favorable results were obtained by Serim et al. [12] in an experiment in sunflower cultivation, where strip spraying with non-selective herbicide with shields in inter-rows was also used and selective herbicides were used in rows.

Sugar cane growers from Australia have also noticed the benefits of spraying in the shield, bypassing the crops. According to Hunt [13], the solution that allows the application of herbicides to weeds, bypassing the crop, reduced spray liquid drift. Vegetable growers who apply glufosinate in a strip manner have improved the effectiveness of weed control without damaging the crop cultivation [14,15]. Additionally, the studies by Foster et al. [16] show the beneficial effect of the use of shields to reduce the working liquid drift. Under the set conditions of comparative tests, at a wind speed of $11-14\left(\mathrm{~km} \cdot \mathrm{h}^{-1}\right)$, relative drift at a distance of up to $7(\mathrm{ft})$ was definitely different for the two spraying methods. Shielded spraying reduced the fine drop drift to $20 \%$, where virtually $100 \%$ of fine drops were carried away by conventional spraying without shields. In the case of medium drops, it was below $20 \%$ for spraying with shields and more than $60 \%$ for conventional spraying. For very coarse drops, less than $10 \%$ of the liquid was carried away in shielded spraying, and less than $20 \%$ of the liquid was carried away in conventional spraying. On the other hand, when spraying with ultrathick drops, less than $5 \%$ of the liquid was carried away in shielded spraying and less than $15 \%$ in conventional spraying. Clayton's [17] research shows that the use of shields in the wind tunnel reduces the drift at a wind speed of $2 \mathrm{~m} \cdot \mathrm{s}^{-1}$ and at a distance of up to $7 \mathrm{~m}$ against the wind between 95 and $100 \%$ for all tested sprayers. Many other researchers confirm that for some crops strip application allows a reduction in the amount of spray liquid used to $60 \%$ due to the smaller actual spraying area, which is not without significance for the environment and crops [18-26]. Appropriate construction of the sprayer enables the additional application of other pesticides or fertilizers during one treatment, which in connection with precise automatic steering with an accuracy of 2-3 cm improves the economic and environmental aspect of this technology.

Another method of reducing herbicide consumption is the variable dosage of the working liquid based on real-time image analysis [27-30]. Research in this area carried out by Dammer et al. [31] allowed the attainment of a yield at a level similar to the conventional application of herbicides. The methods consisted of the minimal application of herbicides when weeds were not detected and an increased application to the required level if weeds were detected. In research years of 2007 and 2010, this allowed them to save herbicides at the level of $30-43 \%$. Both crop quality and total and commercial yield did not show statistical differences compared to conventional herbicide application.

The aim of this work was to develop a technology for the precise application of herbicides in field onion cultivation using the row-strip method, the main pillars of which are: an automatic steering system of a farm tractor and a designed sprayer with an innovative multifaceted adjustment of the spraying unit equipped with a herbicide shield. The proposed solution is to ensure a precise application of plant protection products in various field vegetable cultivation systems, which will reduce the likelihood of active substances accumulating in the crop and the occurrence of phytotoxicity in the case of onions. In addition, a precise application enables the limitation of the dose of active substances per $1 \mathrm{ha}$ of sprayed area, as well as performing effective treatments at wind speeds exceeding 
$4 \mathrm{~m} \cdot \mathrm{s}^{-1}$. Adjusting the level of weed infestation in the developed technology enables onion yielding at a level comparable to that achieved when using conventional technology.

\section{Materials and Methods}

The research material was an onion plantation during 3 growing seasons in 2015/2016, 2016/2017, 2017/2018. Cultivation conditions were the same for all plots covered by the experiment (i.e., pre-crop, tillage, variety, sowing technique, fertilization and plant protection products, crop harvest).

Onions were grown in row-strip method with a spacing of $150 \mathrm{~cm}$. The seeding was carried out with a $71 \mathrm{~kW}$ tractor, equipped with narrow tires for inter-row cultivation, i.e., at the front: $210 / 95 \mathrm{R} 36$, and at the rear: $230 / 95 \mathrm{R} 48$. A precise pneumatic seed drill with onion sowing discs was mounted on the rear three-point linkage. In addition, the tractor was equipped with an automatic steering system with an accuracy of $2 \mathrm{~cm}$ with RTK NET signal correction. In one strip, 4 double rows were sown at a spacing of $7 \mathrm{~cm}$ in the section and $27 \mathrm{~cm}$ between the extreme rows of adjacent sections. The working speed during sowing was $4.0 \mathrm{~km} \cdot \mathrm{h}^{-1}$. Depending on the conditions in the field, the sowing depth was $2.0-2.5 \mathrm{~cm}$.

The variety was selected based on the recipient requirements and varietal breeder's recommendations, in accordance with their requirements. According the breeder's data, this variety has high dry mass content of $12-13 \%$, suitable for dried production and longterm storage.

Selected cultivation areas were characterized by the most homogeneous soil and climatic conditions and the presence of weeds, pests and diseases of similar intensity. The size, placement of the plots and the manner of conducting the experiment were based on the guidelines contained in the standards of the European and Mediterranean Plant Protection Organization regarding the assessment of the effectiveness of plant protection products.

The experimental unit in the study was plots of $10.5 \mathrm{~m}^{2}$ and a size of $7.0 \times 1.5 \mathrm{~m}$, arranged in a Latin square. Each of the objects appeared only once in each row and column. The number of objects was equal to the number of rows, the number of columns and the number of objects' repetitions. Due to the possibility of neighborly interaction and the possibility of the drift of liquids during spraying, $1.5 \mathrm{~m}$ wide insulation strips were set between the plots within the row and $10.0 \mathrm{~m}$ between the plots along the column (Figure 1).

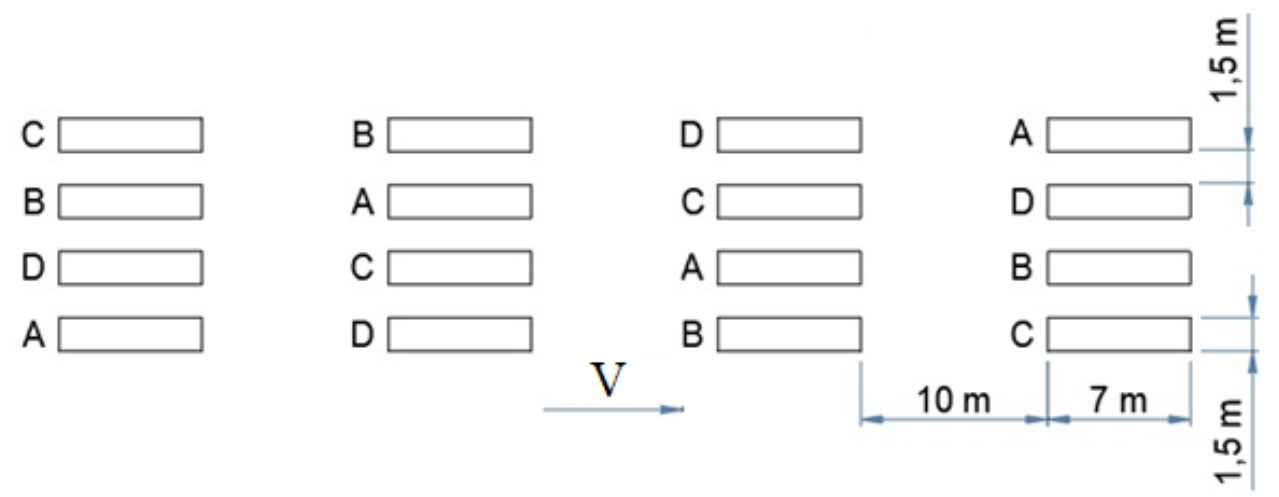

Figure 1. A diagram of the placement of experimental plots in onion cultivation, including plot size and insulation strips (source: own work).

The experimental factor was the method of weed control on the plots. The following methods of weed control were adopted in the research: A-without weeding (control); B-manual weed control (manual weeding); C-conventional herbicide application; Dprecise herbicide application (strip type with herbicide shield, using an automatic steering system). The number of observations for each method was 4 . 
The following herbicides were used during the research: Agil 100EC, Pendigan 330EC, Roundup 360SL, Galigan 240EC, Goal 480SC, Lontrel 300SL, Emblem 20WP, Fusilade Forte 150EC, Szogun 10EC, Lentagran 45WP.

The date of herbicide application resulted from the assessment of crop and weed development stages, as well as weather conditions. During the entire growing season of onions in 2016, there was $284 \mathrm{~mm}$ of precipitation recorded, and the irrigation was $50 \mathrm{~mm}$. During the growing season, ground frost occurred: April 1: $-1{ }^{\circ} \mathrm{C}$, April 2: $-4{ }^{\circ} \mathrm{C}$, April 3: $-1{ }^{\circ} \mathrm{C}$, April 23: $-2.5^{\circ} \mathrm{C}$, April 25: $-3.5^{\circ} \mathrm{C}$, April 26: $-3{ }^{\circ} \mathrm{C}$ and April 29: $-1{ }^{\circ} \mathrm{C}$. The precipitation in the amount of $317 \mathrm{~mm}$ and the irrigation of $35 \mathrm{~mm}$ were noted during the growing season of onions in 2017. During the growing season, ground frosts also occurred: April 19: $-1.5^{\circ} \mathrm{C}$ and May 9 and 10: $-4{ }^{\circ} \mathrm{C}$. In the growing season of 2018, the precipitation of $225 \mathrm{~mm}$ was noted in onion cultivation, while irrigation was $150 \mathrm{~m}$.

Precipitation and irrigation measurements in all analyzed periods included a period of seven days before sowing to the day of crop harvesting.

Conventional spraying of onions was carried out using a trailed sprayer with a working beam width of $18 \mathrm{~m}$. The sprayer was equipped with wheels with narrow tires for inter-row cultivation (270/95R48). The tractor also had narrow tires for inter-row cultivation, i.e., at the front 270/95R32 and at the rear 270/95R46. The working speed during spraying was $7.0 \mathrm{~km} \cdot \mathrm{h}^{-1}$ and the working pressure was $3.5 \mathrm{bar}$, and the universal injector flat spray nozzles AirMix 110-03 producing coarse drops were used.

Precise spraying was carried out using a designed and made prototype sprayer with herbicide shield and strip nozzles TeeJet TP9501EVS and TeeJet TP9502EVS, producing fine drops and using an automatic steering system with declared accuracy of $2 \mathrm{~cm}$. The working speed was $6 \mathrm{~km} \cdot \mathrm{h}^{-1}$ and the working pressure was $2.5 \mathrm{bar}$.

Strip nozzles enable the height of the boom to be lowered significantly in relation to the area to be sprayed. This improves application precision. The spray belt width can be adjusted either by changing the boom height or by rotating the nozzle in relation to its axis. In the tests, the height was $0.18 \mathrm{~m}$-this gave a spray strip width of $0.40 \mathrm{~m}$.

The total sprayed area in strip row cultivation of onions is smaller than in the case of conventional spraying. This was due to the small distance between the rows within the single sowing section $(7 \mathrm{~cm})$. On the other hand, the spraying sections were arranged in strips between the rows of adjacent two-row sections and in spaces between the extreme rows of adjacent strips (Figure 2).

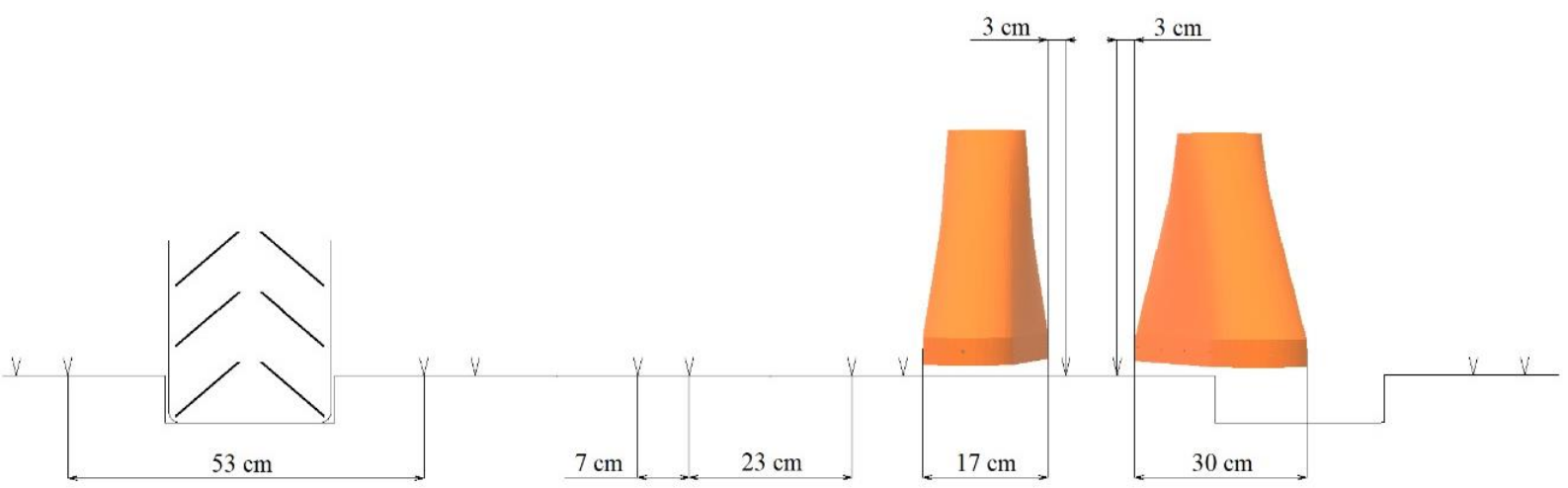

Figure 2. The width of sprayed strips and the arrangement of spraying sections in strip-row onion cultivation (source: own work).

The width of the sprayed strip during precise spraying in onion cultivation was adjusted by the nozzle rotation in its vertical axis and changing the distance from the sprayed surface in accordance with the manufacturers' recommendations for strip spraying.

Harvest dates were in line with those contained in the crop cards and resulted from the maturity of crops and the end of the onion growing season. Harvesting of all plots in the experiments was performed manually to reduce possible mechanical damage. Onions 
were harvested according to the most commonly used technology, i.e., in two stages. First, the onions were dug up and laid in rows. During the studies carried out, the yield from each plot was stored separately and marked accordingly. After drying, the onions were collected and stripped to $2-3 \mathrm{~cm}$ in length using the propeller cutter.

\section{Results}

In 2016, the highest average total yield of $83.3 \mathrm{t} \cdot \mathrm{ha}^{-1}$ was recorded from manually weeded objects, and a slightly lower yield, namely, $80.5 \mathrm{t} \cdot \mathrm{ha}^{-1}$, was recorded from objects sprayed in the conventional way. A total yield of $79.7 \mathrm{t} \cdot \mathrm{ha}^{-1}$ was recorded from precisely sprayed objects, and the lowest one was recorded from the control objects, $-42 \mathrm{t} \cdot \mathrm{ha}^{-1}$. The average height of the commercial yield was subjected to the same distribution: as in the case of the total yield, the highest height was recorded from objects weeded manually $\left(81.8 \mathrm{t} \cdot \mathrm{ha}^{-1}\right)$, then from conventionally sprayed objects $\left(79.4 \mathrm{t} \cdot \mathrm{ha}^{-1}\right)$ and from objects sprayed in a precise way $\left(78.5 \mathrm{t} \cdot \mathrm{ha}^{-1}\right)$, and the lowest height was recorded from control objects $\left(39.5 \mathrm{t} \cdot \mathrm{ha}^{-1}\right)$. The amount of non-commercial yield looks different. The highest average value was noted on control objects $\left(2.5 \mathrm{t} \cdot \mathrm{ha}^{-1}\right)$, a slightly lower one was noted on the manually weeded objects and those sprayed precisely $\left(1.2 \mathrm{t} \cdot \mathrm{ha}^{-1}\right)$, and the lowest on objects sprayed conventionally $\left(1.1 \mathrm{t} \cdot \mathrm{ha}^{-1}\right.$ ) (Figure 3 ).

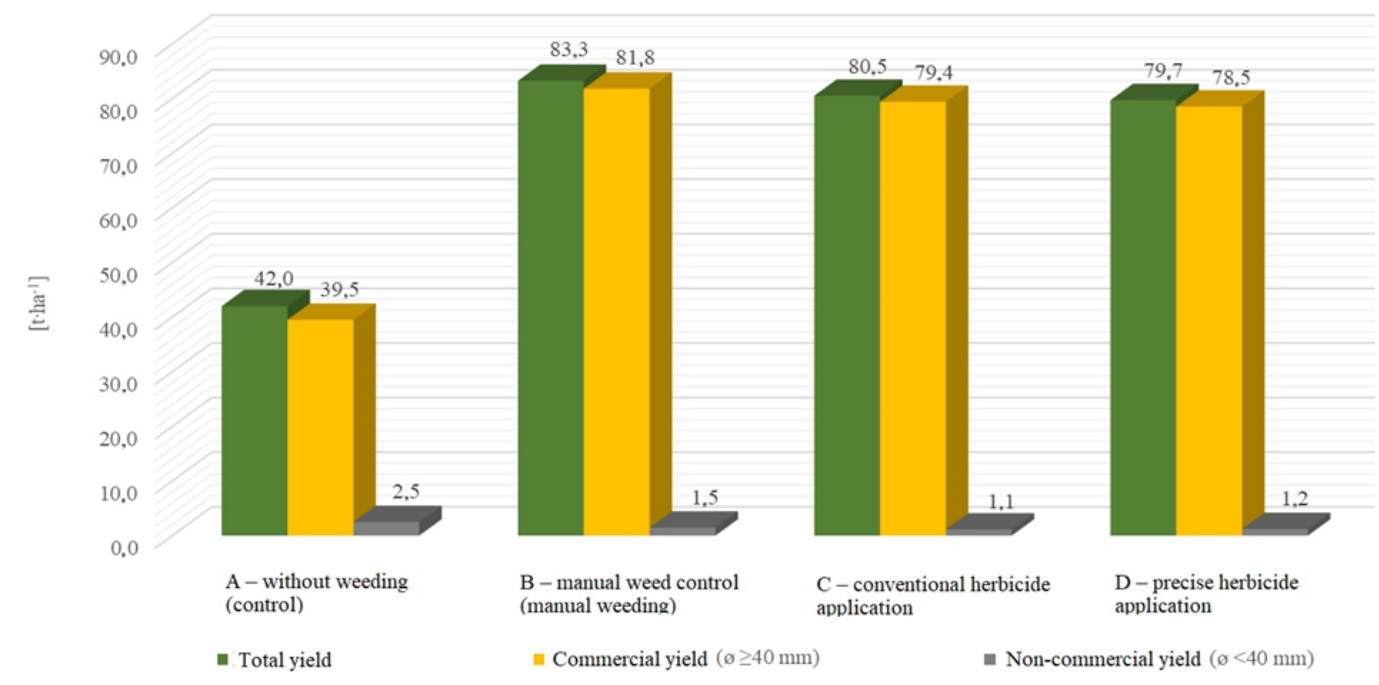

Figure 3. Average onion yield in 2016 (source: own work).

The total onion yield did not differ statistically within the accepted confidence interval, regardless of the weeding method. Objects weeded manually (B) and those sprayed in the conventional way $(\mathrm{C})$ and in a precise way (D) yielded the same level. The difference in yield was only in the case of the control object (A), which was not weeded (Figure 4).

Similarly, in the case of commercial yield in the 0.95 confidence intervals, the yield did not differ regardless of the weeding method. Only the control object yielded at a much lower level (Figure 5). 


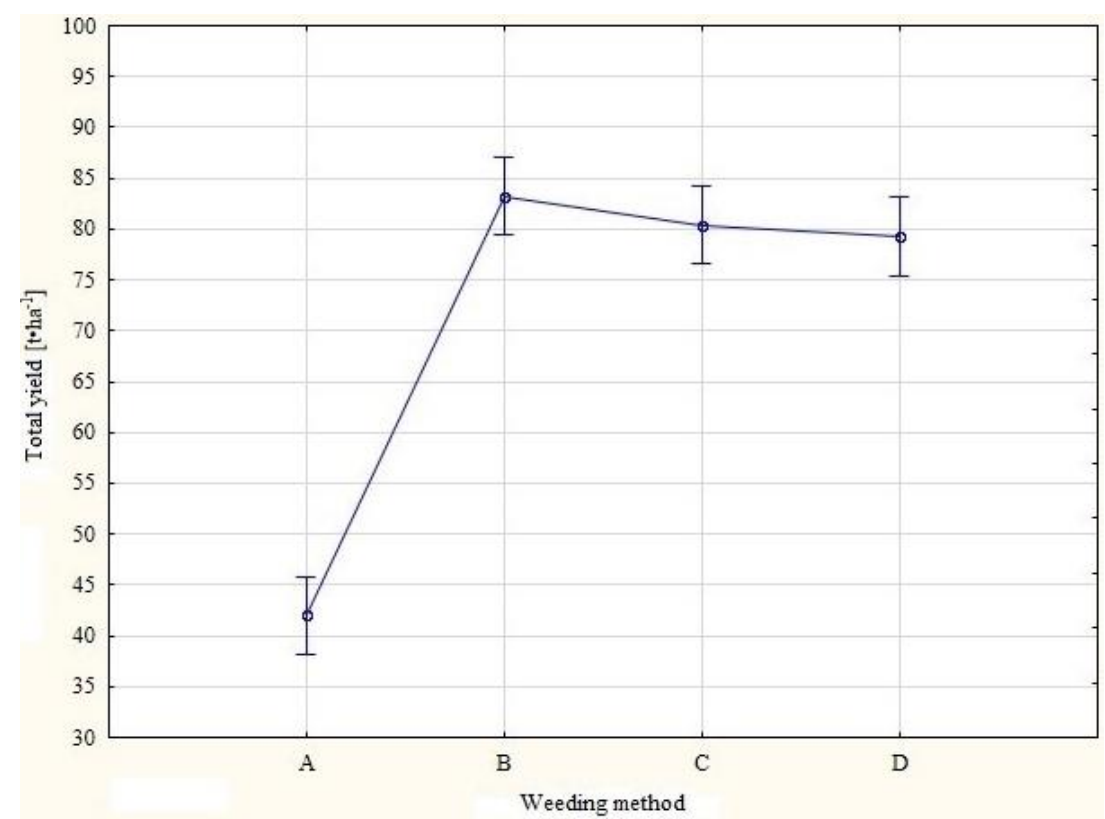

Figure 4. Expected marginal averages for 0.95 confidence intervals in total onion yield in 2016 (source: own work).

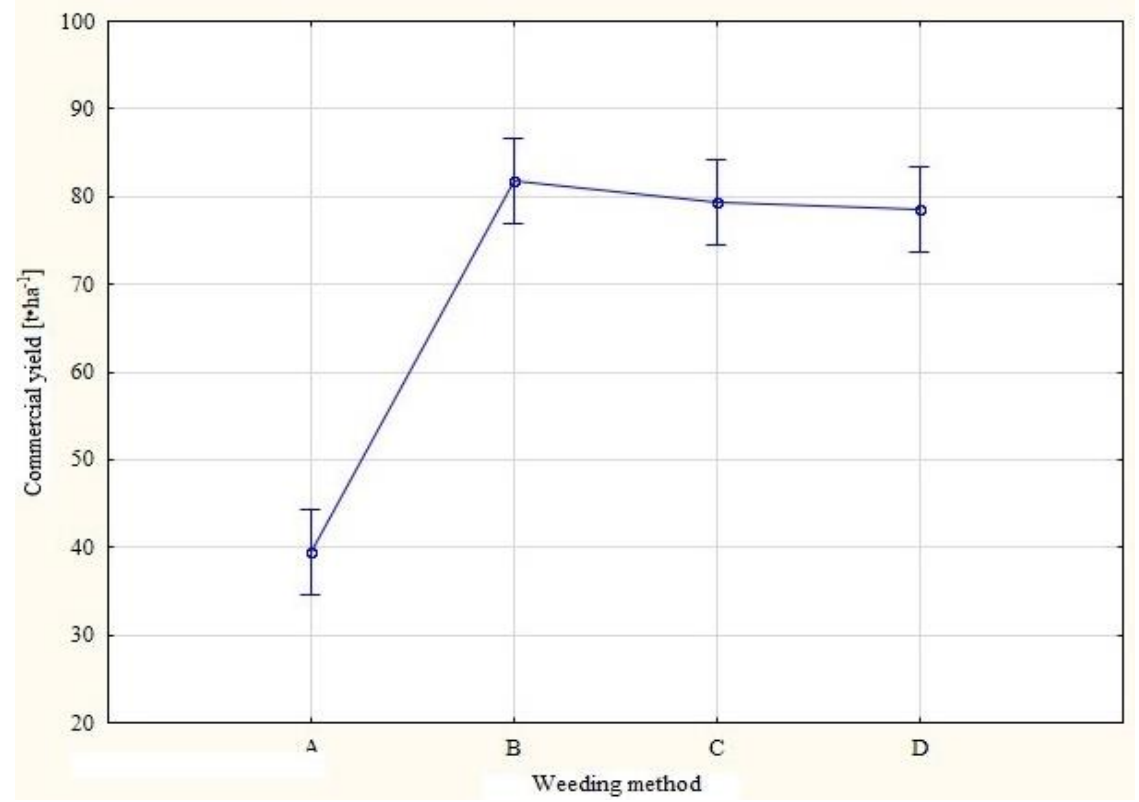

Figure 5. Expected marginal averages for 0.95 confidence intervals in commercial onion yield in 2016 (source: own work).

The share of individual fractions in total yield in 2016 varied depending on weed control methods. The non-commercial yield was the highest in the case of control objects, and the average was $2.5 \mathrm{t} \cdot \mathrm{ha}^{-1}$. Nearly $34 \mathrm{t} \cdot \mathrm{ha}^{-1}$ was an average harvest of the $40-60 \mathrm{~mm}$ fraction in the case of the control objects, while about $55 \mathrm{t} \cdot \mathrm{ha}^{-1}$ was for various weeding methods. At a similar level of about $25 \mathrm{t} \cdot \mathrm{ha}^{-1}$, the average yield of the $60-70 \mathrm{~mm}$ fraction was harvested from objects marked as B and C, whereas almost $19 \mathrm{t} \cdot \mathrm{ha}^{-1}$ was collected from objects marked as D. The highest average yield for the fraction above $70 \mathrm{~mm}$ was achieved in manual weeding and precise spraying, slightly over $2 \mathrm{t} \cdot \mathrm{ha}^{-1}$, while in conventional spraying it was $1.4 \mathrm{t} \cdot \mathrm{ha}^{-1}$. On control objects, this fraction averaged only $0.1 \mathrm{t} \cdot \mathrm{ha}^{-1}$ (Figure 6). 


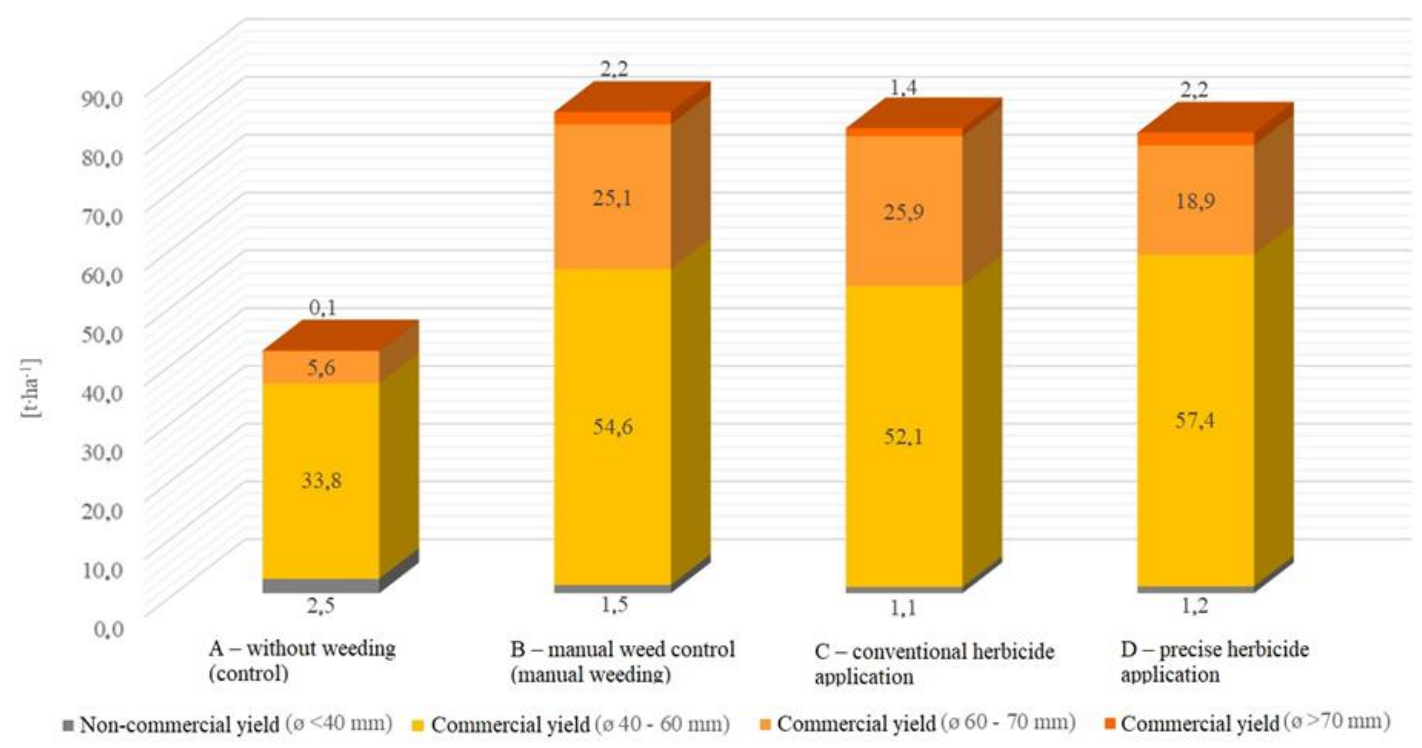

Figure 6. Average onion yield divided into fractions in 2016 (source: own work).

In subsequent years of research, i.e., in 2017, in the case of non-commercial yield, its quantity was the largest in control objects and amounted to $3.8 \mathrm{t} \cdot \mathrm{ha}^{-1}$, whereas it was slightly more than $1.5 \mathrm{t} \cdot \mathrm{ha}^{-1}$ in other cases. The average commercial yield for the methods marked as $C$ and D was at a similar level and amounted to about $58 \mathrm{t} \cdot \mathrm{ha}^{-1}$, similarly to the total yield (about $60 \mathrm{t} \cdot \mathrm{ha}^{-1}$ ) and slightly higher for the B method, and amounted to about $63 \mathrm{t} \cdot \mathrm{ha}^{-1}$ (commercial yield) and almost $65 \mathrm{t} \cdot \mathrm{ha}^{-1}$ (total yield). The control was characterized by a total yield of $38.7 \mathrm{t} \cdot \mathrm{ha}^{-1}$ and a commercial yield of $34.9 \mathrm{t} \cdot \mathrm{ha}^{-1}$ (Figure 7).

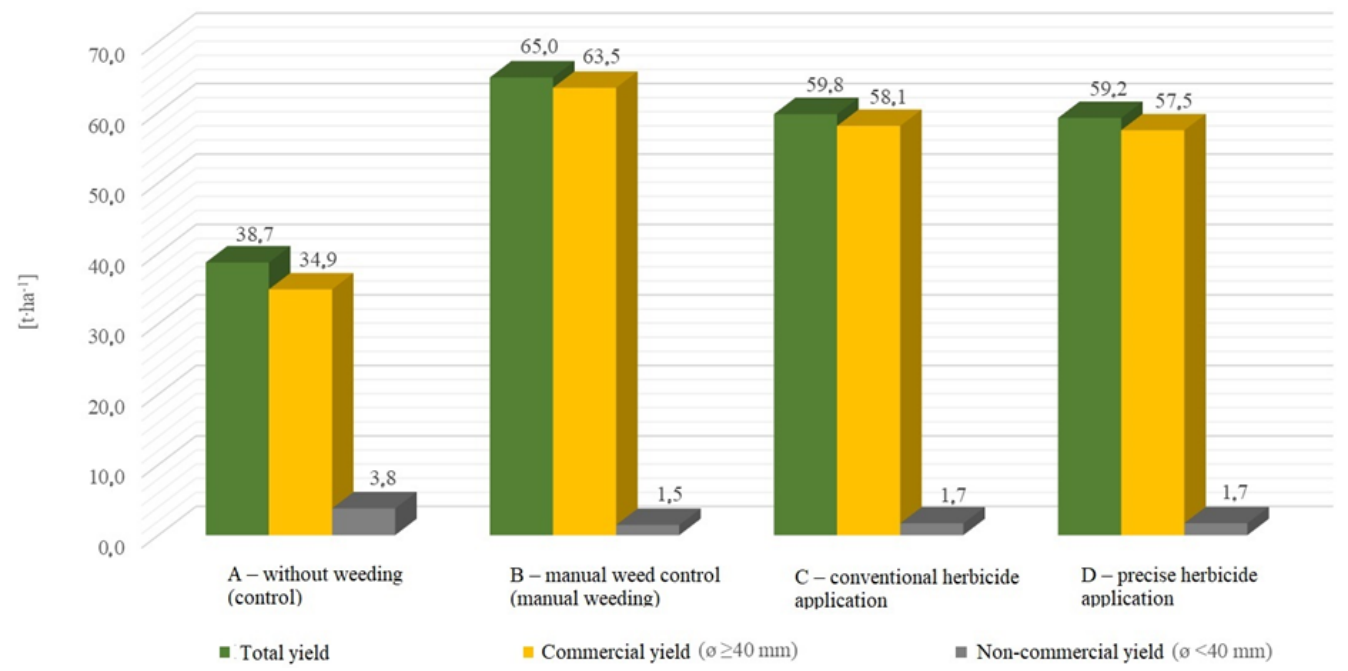

Figure 7. Average onion yield in 2017 (source: own work).

When comparing total and commercial statistical yield, also in 2017 there were no differences between weeding methods. Total and commercial yield in the case of control objects was significantly lower compared to objects weeded with various methods (Figures 8 and 9). 


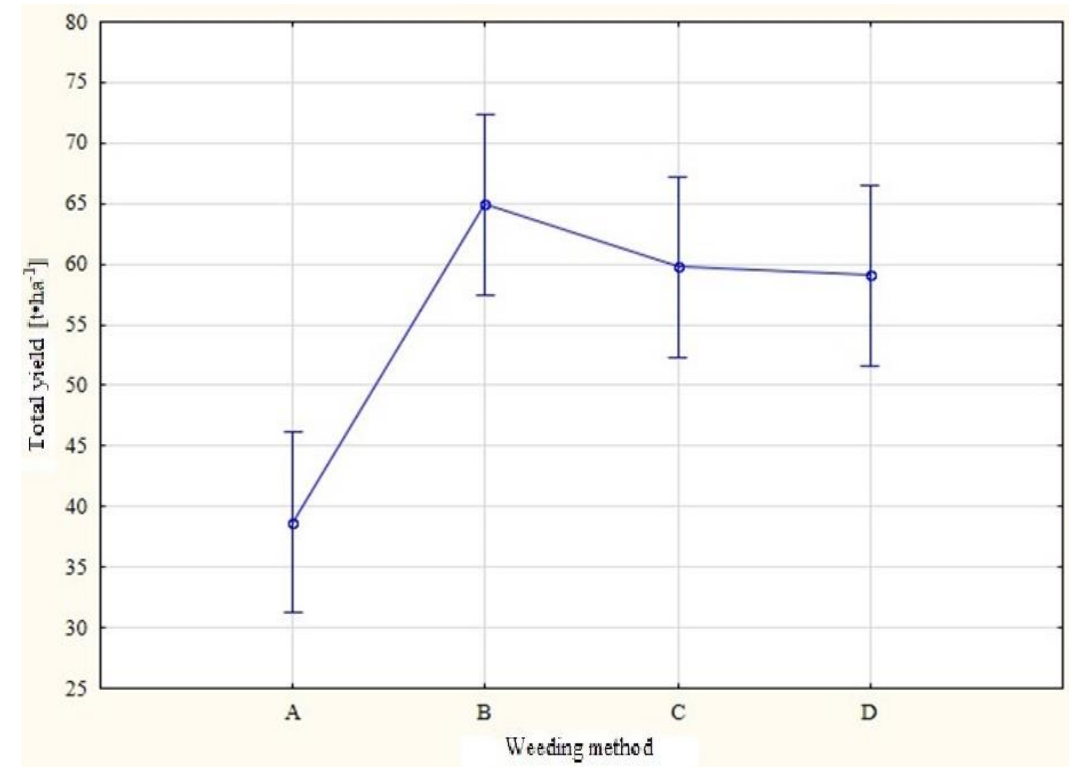

Figure 8. Expected marginal averages for 0.95 confidence intervals in total onion yield in 2017 (source: own work).

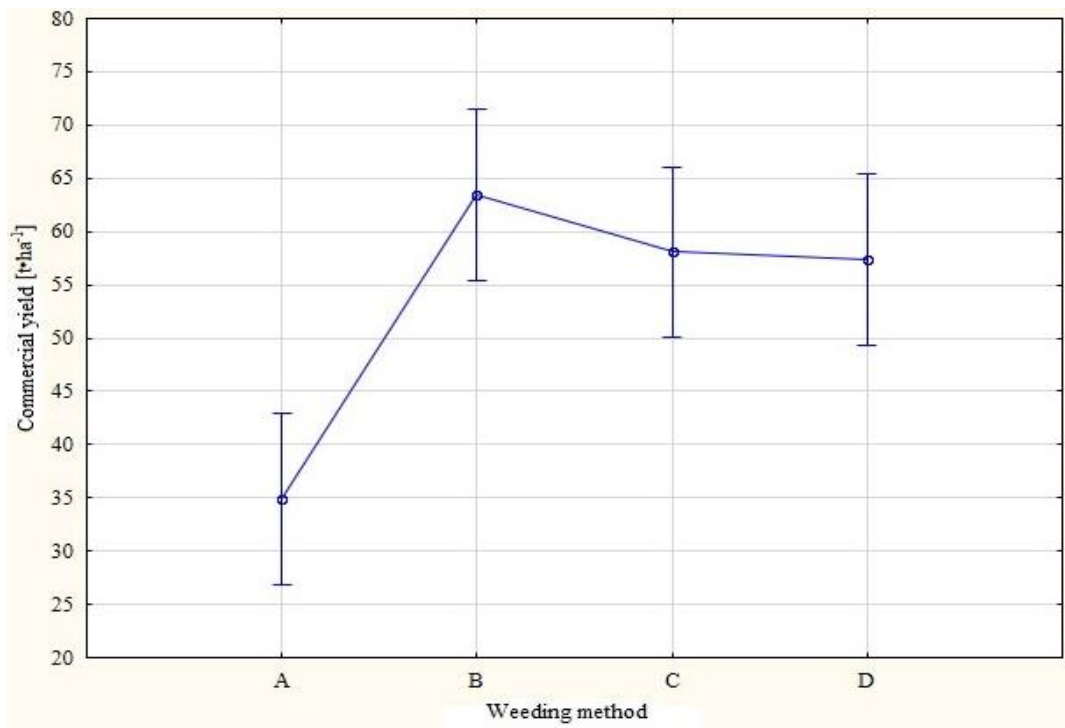

Figure 9. Expected marginal averages for 0.95 confidence intervals in commercial onion yield in 2017 (source: own work).

The average share of individual fractions in the yield for individual objects in 2017 is shown in Figure 10. The non-commercial fractions, in the case of various weeding methods, yielded between 1.5 and $1.7 \mathrm{t} \cdot \mathrm{ha}^{-1}$, and for control objects it was $3.8 \mathrm{t} \cdot \mathrm{ha}^{-1}$. The $40-60 \mathrm{~mm}$ fraction was at a similar level for methods A, B and C, whereas this fraction was slightly less in control objects (about $28 \mathrm{t} \cdot \mathrm{ha}^{-1}$ ). A similar level of the $60-70 \mathrm{~mm}$ fraction was characteristic for methods $C$ and $D$. The amount of the $60-70 \mathrm{~mm}$ fraction was the largest for method B and amounted to almost $28 \mathrm{t} \cdot \mathrm{ha}^{-1}$. The lowest amount, i.e., less than $7 \mathrm{t} \cdot \mathrm{ha}^{-1}$ of this fraction was present in control objects. The largest onions above $70 \mathrm{~mm}$ of the smallest diameter for all methods yielded on average at the level of 1.7 to $2.0 \mathrm{t} \cdot \mathrm{ha}^{-1}$. There was little of this fraction in the case of the control objects (about $0.2 \mathrm{t} \cdot \mathrm{ha}^{-1}$ ). 


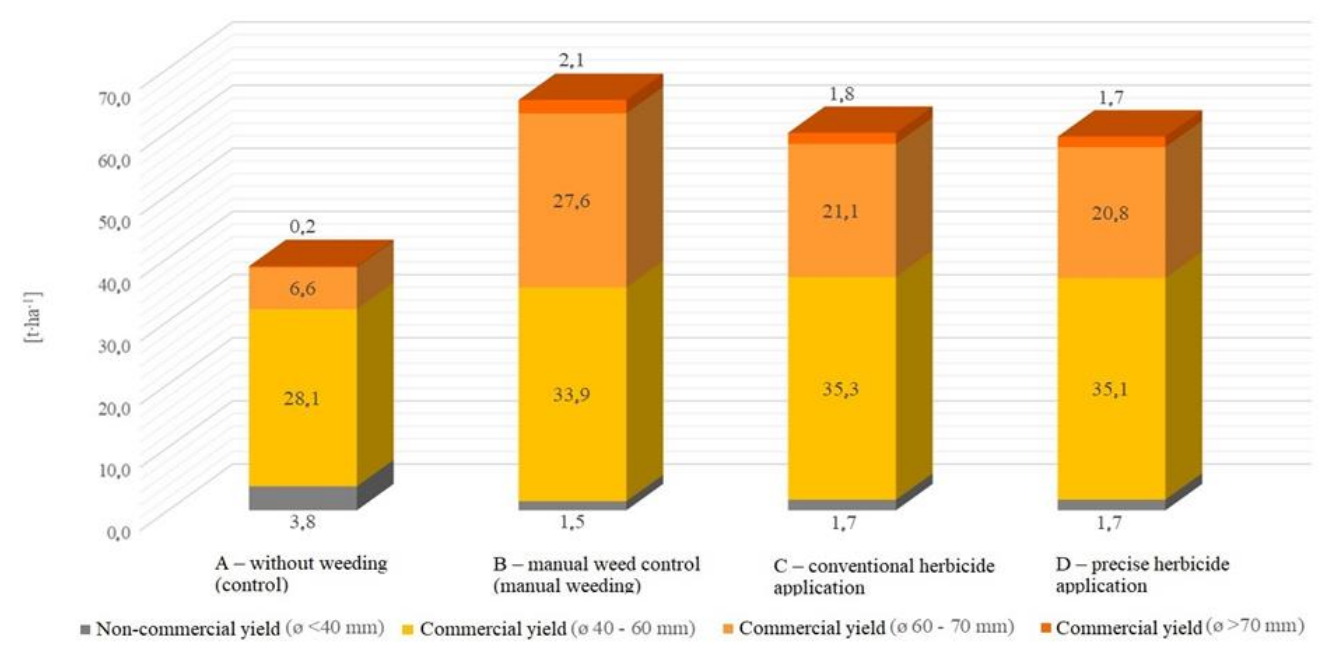

Figure 10. Average onion yield divided into fractions in 2017 (source: own work).

In the experiment in 2018, the total yield was at a lower level than in 2017 and much lower than in 2016. The average yield for individual weeding methods showed a tendency similar to previous years. The highest average total yield was obtained in this case for method B (nearly $56 \mathrm{t} \cdot \mathrm{ha}^{-1}$ ). For methods $\mathrm{C}$ and $\mathrm{D}$, it was at a similar level of $53 \mathrm{t} \cdot \mathrm{ha}^{-1}$. The average commercial yield for the above methods was slightly above $1 \mathrm{t} \cdot \mathrm{ha}^{-1}$ lower than the total yield. The average commercial and total yield in the case of the control objects was over $20 \mathrm{t} \cdot \mathrm{ha}^{-1}$ lower compared to various weeding methods, while the non-commercial one was about $0.5 \mathrm{t} \cdot \mathrm{ha}^{-1}$ higher compared to these methods (Figure 11).

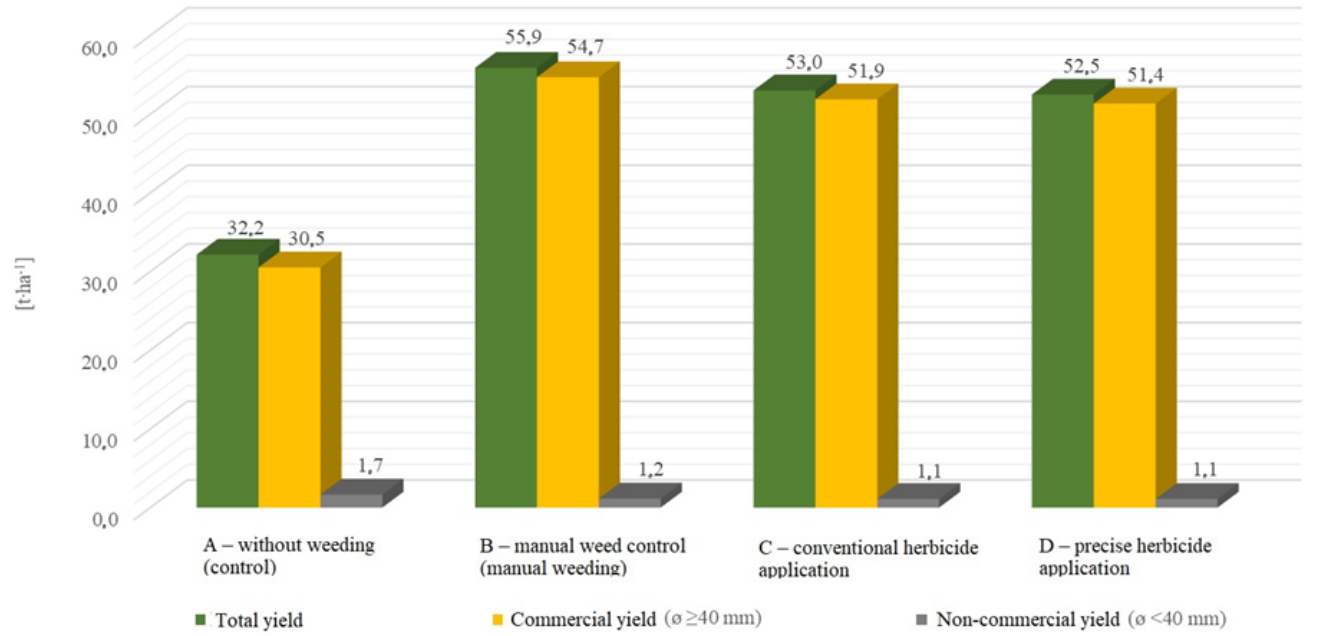

Figure 11. Average onion yield in 2018 (source: own work).

In 2018, the different weeding methods did not differ statistically in terms of total yield. Only the control objects showed a statistically lower yield (Figure 12).

The yield distribution was also similar in the case of commercial yield, where only control objects yielded a lower level (Figure 13). 


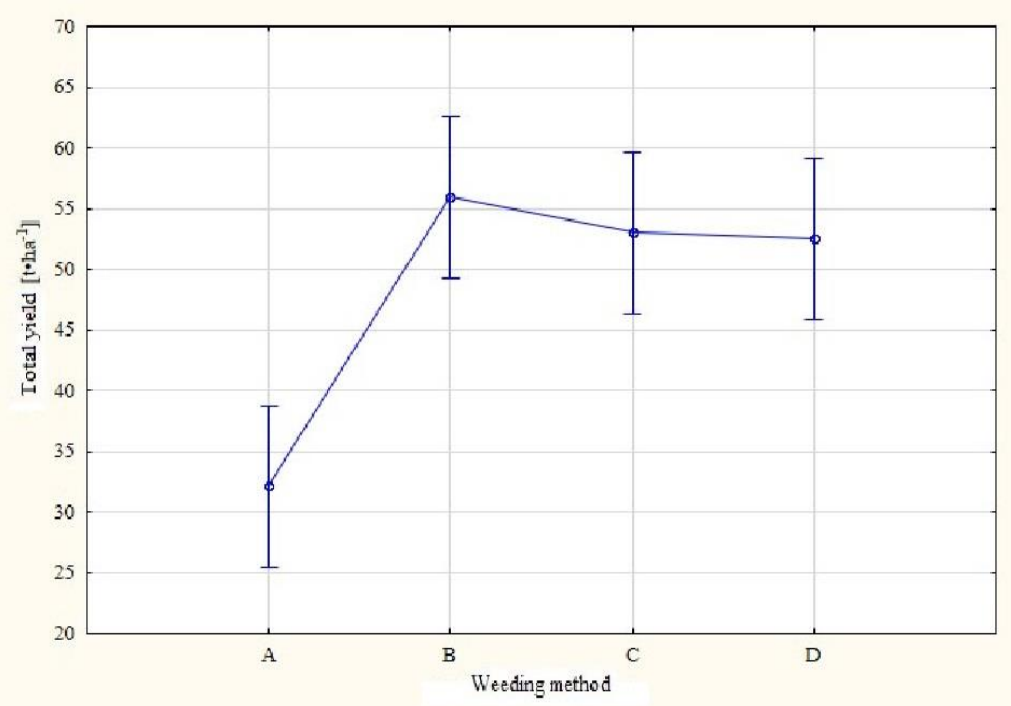

Figure 12. Expected marginal averages for 0.95 confidence intervals in total onion yield in 2018 (source: own work).

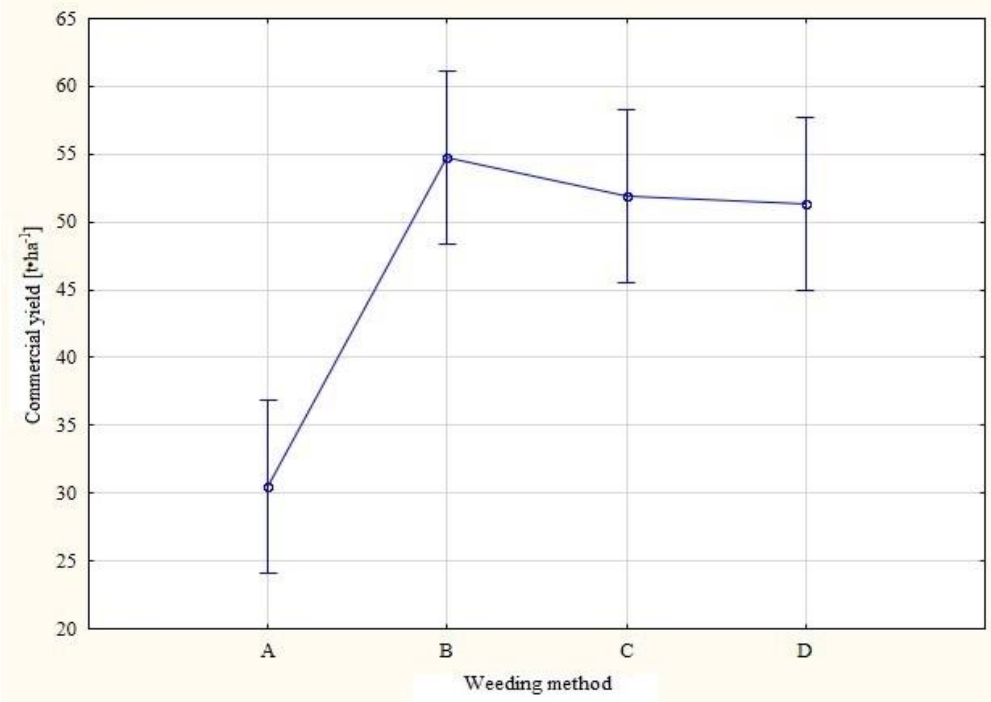

Figure 13. Expected marginal averages for 0.95 confidence intervals in commercial onion yield in 2018 (source: own work).

The share of individual fractions in the average yield collected from the objects in 2018 (Figure 14) was different than in 2016 and 2017. Only the non-commercial yield for control objects and methods B, C and D was at a similar level and amounted to 1.1-1.7 th ha ${ }^{-1}$. The average yield with the fraction with a diameter of $40-60 \mathrm{~mm}$ both in control objects and methods B-D was at a similar level and amounted to about 22 to $26 \mathrm{t} \cdot \mathrm{ha}^{-1}$. In the case of onions with a diameter in the range of $60-70 \mathrm{~mm}$, all the methods are characterized by similar values at the level of about $20 \mathrm{t} \cdot \mathrm{ha}^{-1}$, while the control objects had nearly $8 \mathrm{t} \cdot \mathrm{ha}^{-1}$. In 2018, there was a relatively large share of the largest fraction in methods C-D (7.3-9.5 tha $\left.{ }^{-1}\right)$. In the case of the control, the share of the largest fraction was just over $1 \mathrm{t} \cdot \mathrm{ha}^{-1}$. 


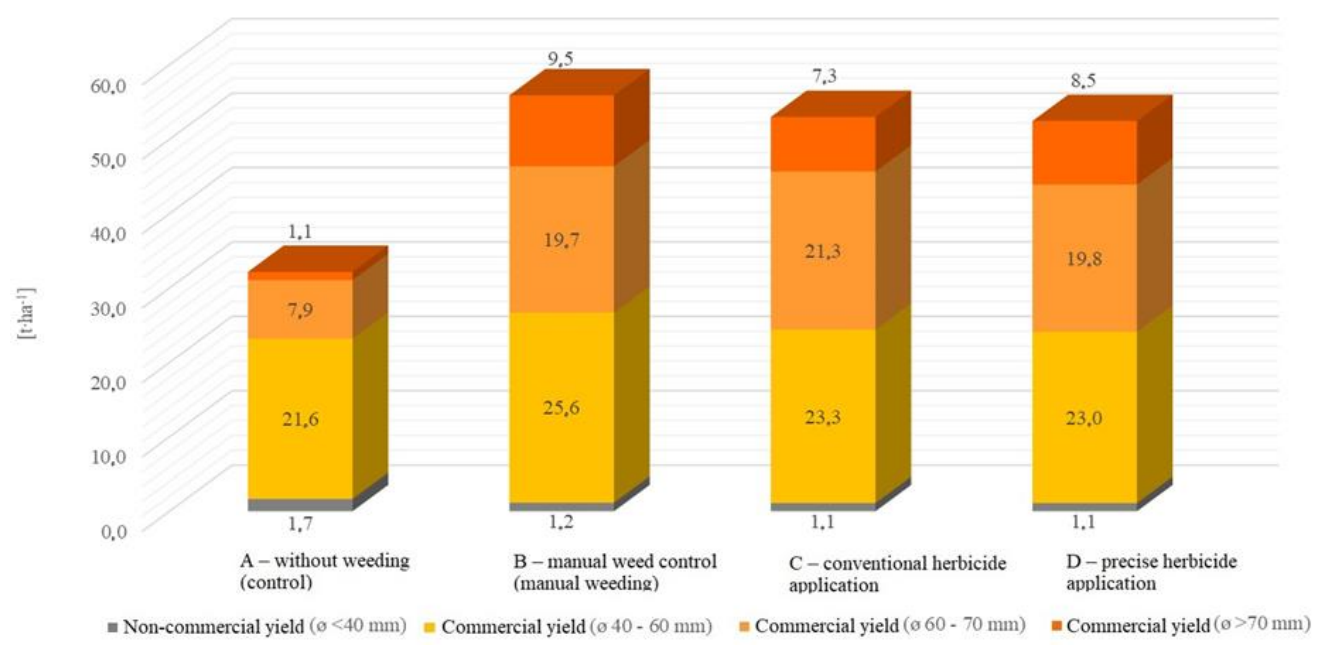

Figure 14. Average onion yield divided into fractions in 2018 (source: own work).

The average weight of one onion in a commercial yield for control and individual weed control methods in 2016-2018 is shown in Figure 15. The control object has always had the lowest average weight of one onion in a commercial yield. The average in 2016 and 2017 was between 85 and $88 \mathrm{~g}$. In 2018, it was higher and amounted to $107 \mathrm{~g}$. The average weight of onions in the commercial yield in 2016 and 2018 was similar in all weed control methods and was in the range of 134-139 g. Only in 2017 were there differences between the average weight of onions. For method B, it was the highest and amounted to $120 \mathrm{~g}$, whereas for methods $\mathrm{C}$ and $\mathrm{D}$ it was at the level of $114 \mathrm{~g}$ and $112 \mathrm{~g}$.

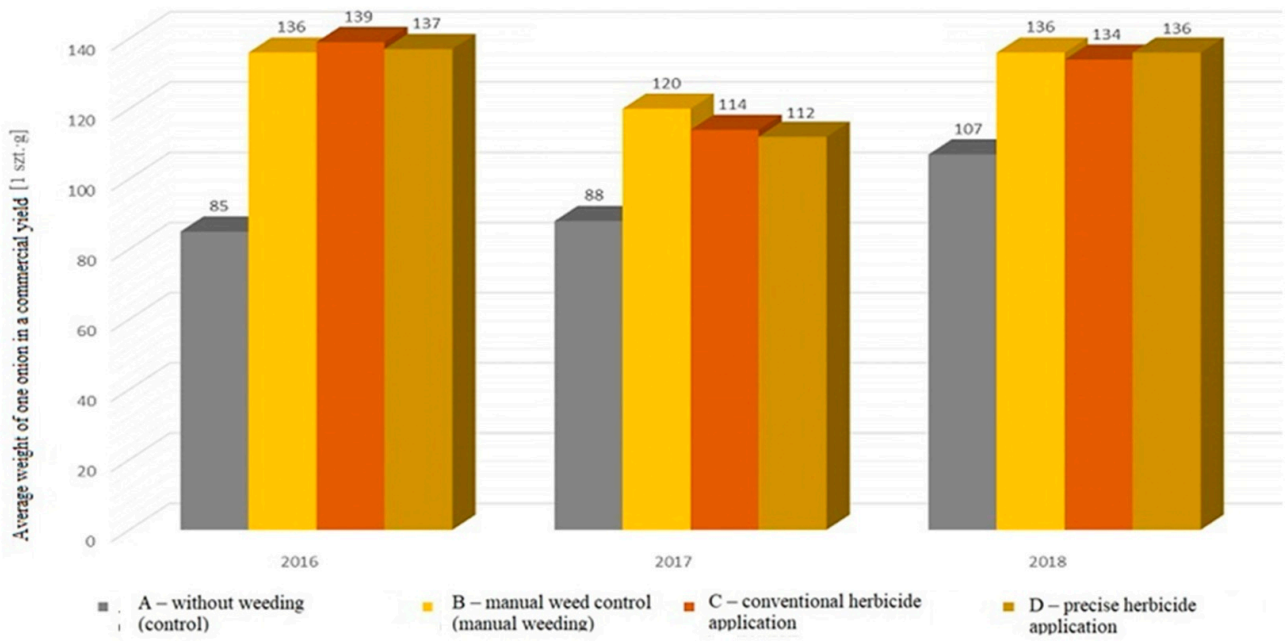

Figure 15. Qualitative assessment of commercial onion yield ( $\varnothing \geq 40 \mathrm{~mm})$ in terms of the average weight of one piece 2016-2018 (source: own work).

The average weight of one onion in the commercial yield was different in individual years of the experiment and statistically the lowest in the case of control objects. However, there were no significant statistical differences between the various weeding methods, as shown in Figures 16-18. 


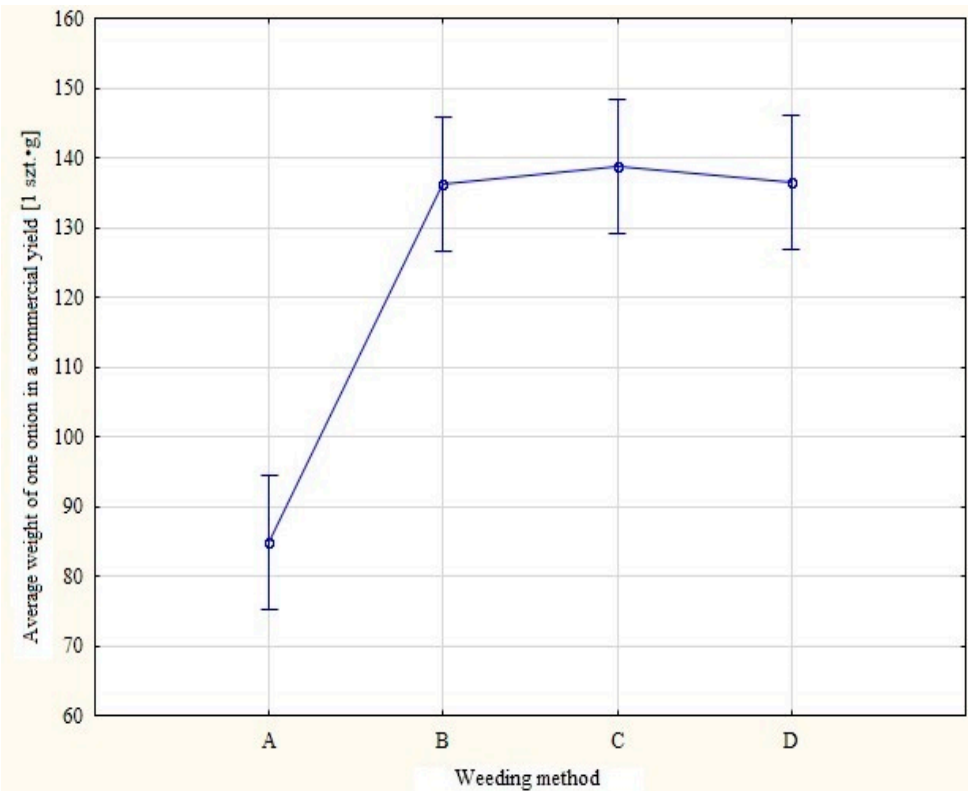

Figure 16. Expected marginal averages for 0.95 confidence intervals for the average weight of one onion in the commercial yield in 2016 (source: own work).

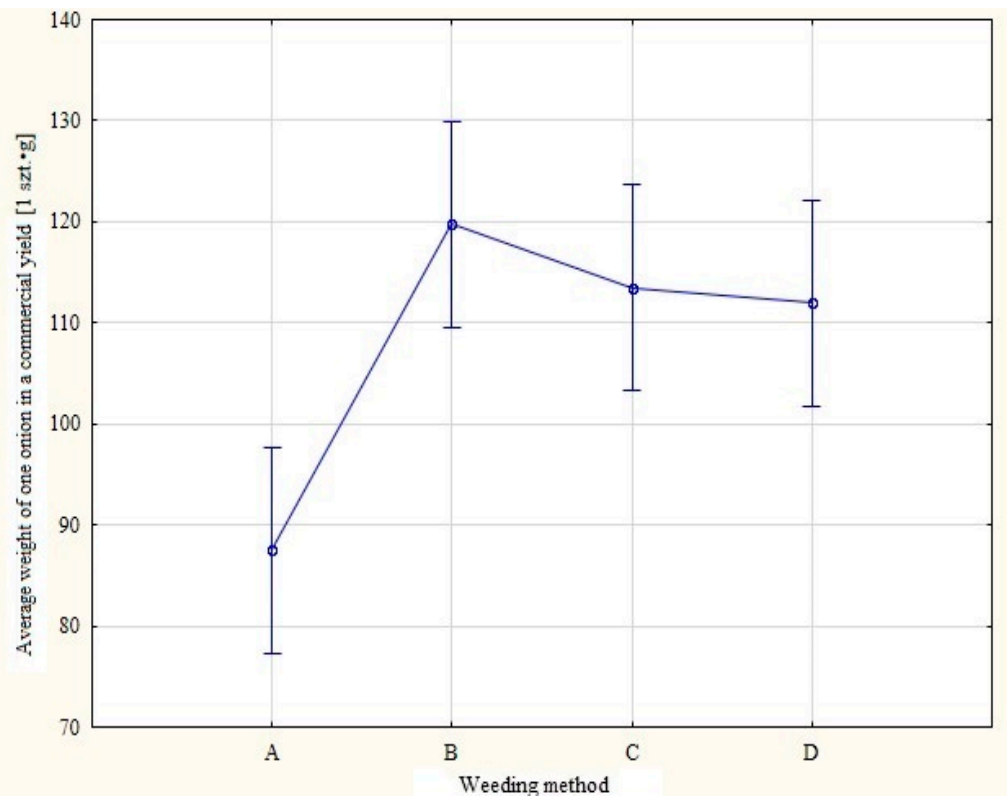

Figure 17. Expected marginal averages for 0.95 confidence intervals for the average weight of one onion in the commercial yield in 2017 (source: own work). 


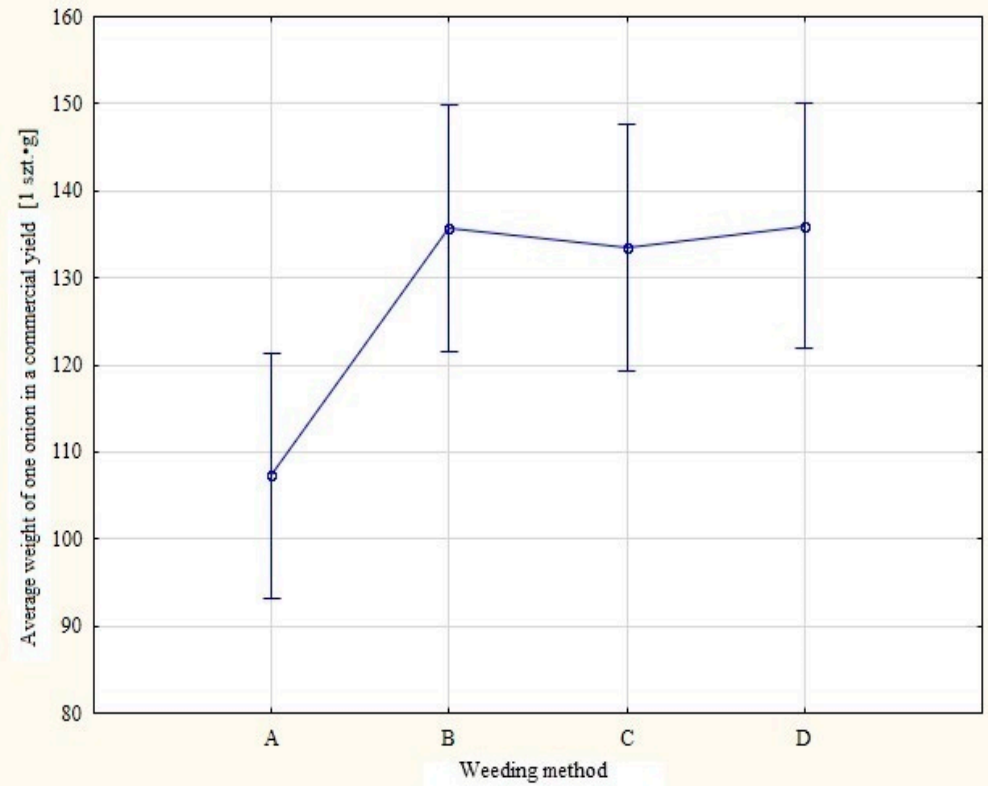

Figure 18. Expected marginal averages for 0.95 confidence intervals for the average weight of one onion in the commercial yield in 2018 (source: own work).

Due to the used methodology, it can be assumed in the cultivation of onions that the years were a random factor, and the experiments carried out were a series. Considering the impact of weeding methods on changes in onion yield in individual years of research, it can be assumed that there is no interaction between the objects and individual years of the experiments, regardless of the weather conditions. Such interaction does not occur for both total and commercial yield and the average weight of one onion in the commercial yield, as shown in Figures 19-21. The onion's response to the change in weeding method is the same, only at a different yield level. It can be assumed that onions, in terms of total yield, commercial yield and the average weight of one onion, yield at the same level regardless of the weeding method. Control objects yield every year at a lower level than the weeded objects, also in terms of the average weight of one onion in the commercial yield.

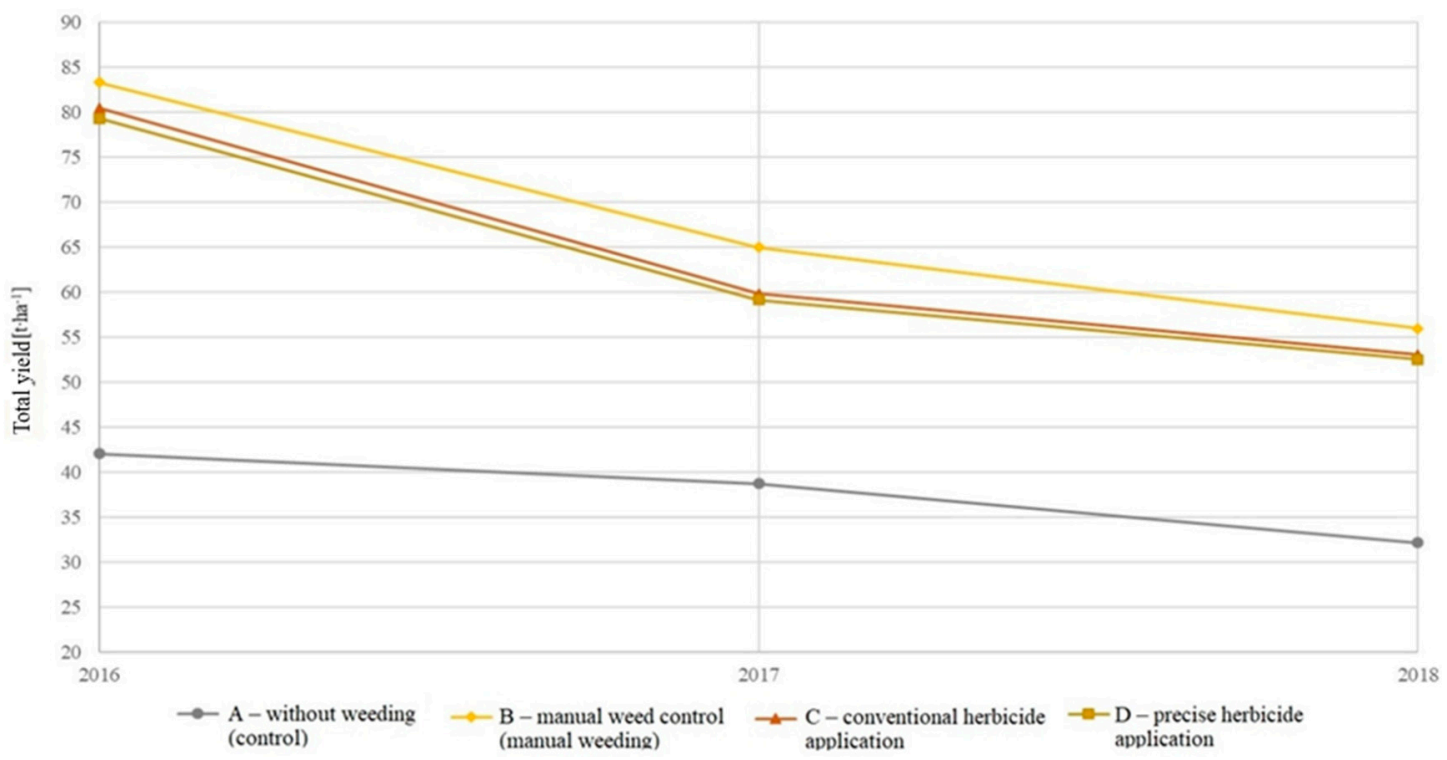

Figure 19. Reaction of total yield to changes in weather conditions depending on the weeding method (source: own work). 


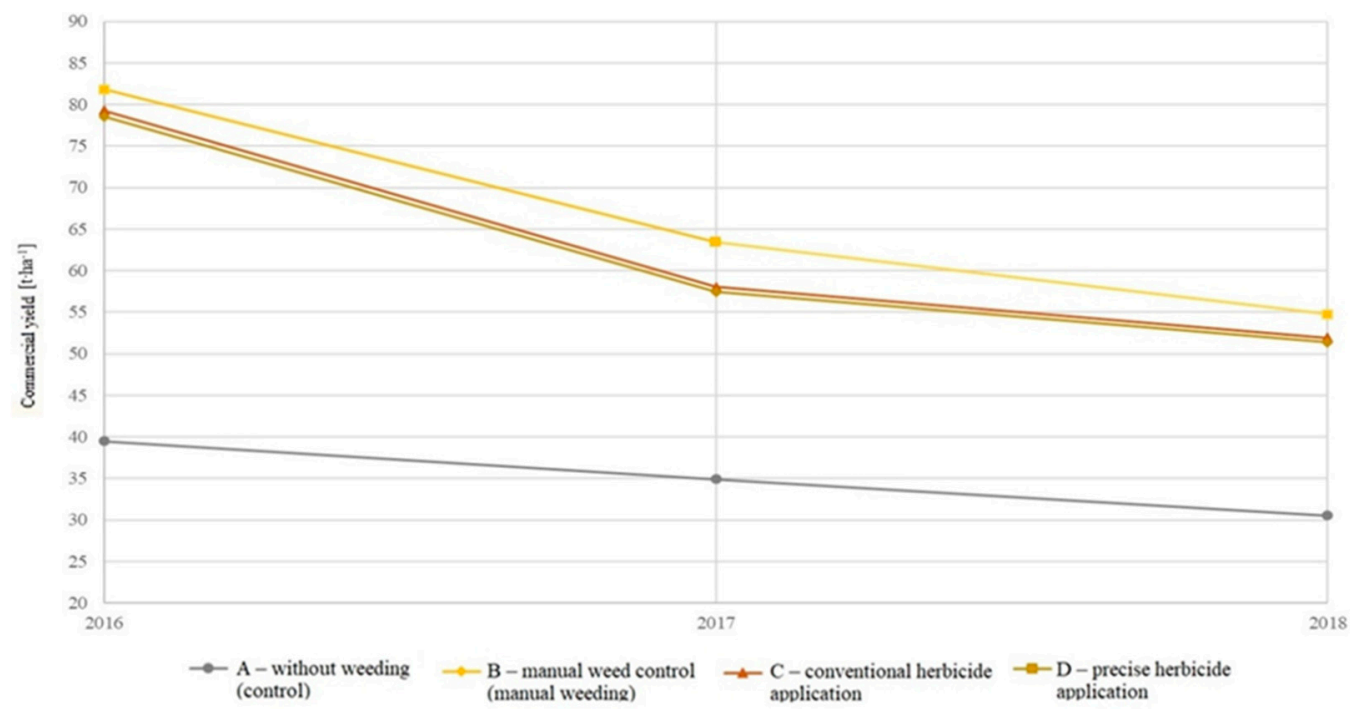

Figure 20. Reaction of commercial yield to changes in weather conditions depending on the weeding method (source: own work).

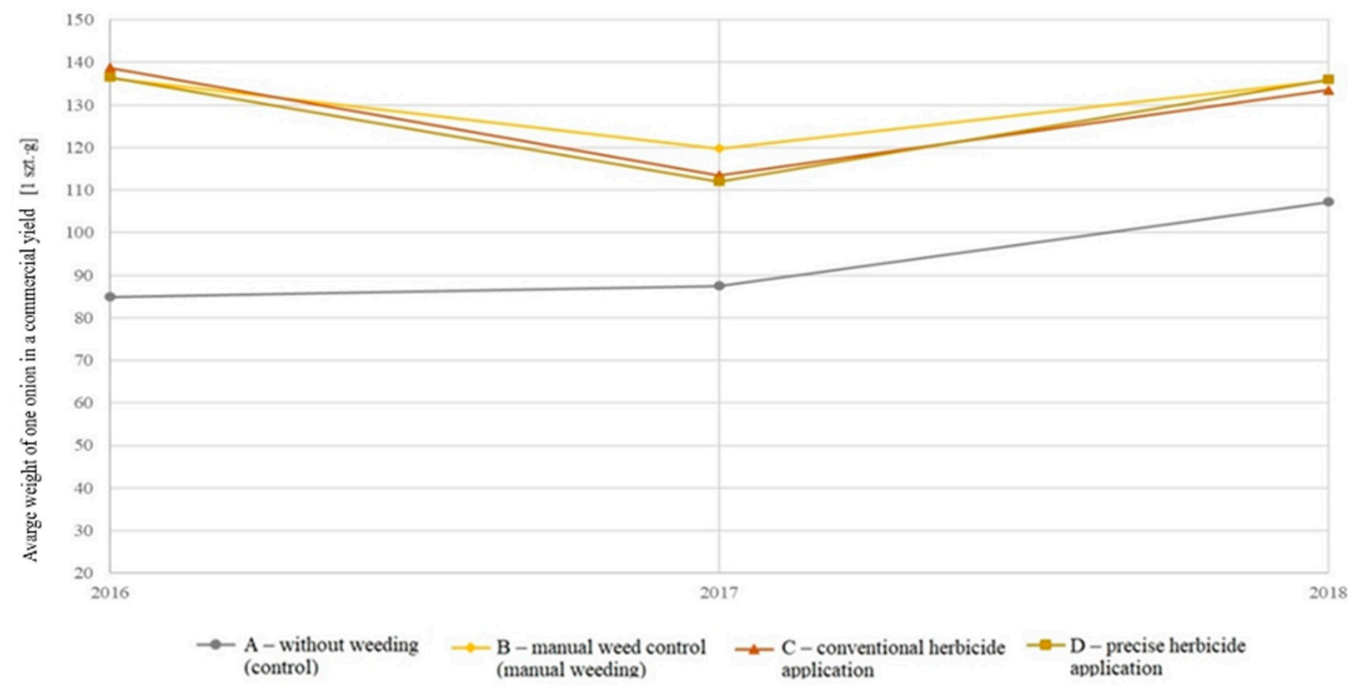

Figure 21. Reaction of the average weight of one onion in the commercial yield to changes in weather conditions depending on the weeding method (source: own work).

\section{Discussion}

This research showed significant differences in the yield between the objects where weeding was carried out with the use of various methods and the control objects where weeding was discontinued. Many researchers around the world note the need to look for different methods and combinations of those methods that are useful in weeding onions. Due to the diversity of habitats and the species composition of weeds and varieties in the case of onions, methods that give satisfactory results are still being sought. A number of studies in various areas allow the formulation of general conclusions underlying the development of herbicide strategies. One example of this approach is research conducted by Rahman et al. [32], where the effectiveness of various weeding methods in onion cultivation was compared. The experiment was carried out using random complete blocks during two growing seasons. In three repetitions there were six objects, where one of them was a control (without weeding). Two methods were based only on manual weeding at different frequencies, whereas the other three methods used different combinations of herbicides. Both in the conducted experiment and in the experiment of Rahman et al. [32], the highest weight of onions was recorded from objects weeded manually with high frequency and 
in the case of one of the chemical methods (the use of pendimethalin), and the lowest one was from control objects without weeding. There were also no statistically significant differences between the onions weeded manually with high frequency and one of the chemical methods-pendimethalin 33\% in terms of yield. Additionally, in the research conducted in 2010-2011, conclusions were drawn confirming the need to control weeds in the cultivation of onions in order to obtain a high and good quality yield. The best results, in terms of yield height and onion diameter, were obtained from objects where weeds were removed manually. For example, the average weight of onions in 2011 from objects weeded manually was $72.8 \mathrm{~g}$, whereas the average weight of onions from objects sprayed once with pendimethalin was $37.2 \mathrm{~g}$. With non-weeded objects, the average weight of onions was $27.2 \mathrm{~g}$ [33].

In our research results presented for the manual weeding method, it was the highest and amounted to $120 \mathrm{~g}$, whereas for conventional herbicide application and precise herbicide application methods, it was at the level of $114 \mathrm{~g}$ and $112 \mathrm{~g}$. However, there were no significant statistical differences between the various weeding methods. What is the benefit? In this situation, the area of herbicide application in onion cultivation was reduced by $26 \%$, which resulted in a reduction in herbicide use by $26 \%$. What is the great advantage of the precise herbicide application method? The cost of the herbicides used is reduced by $26 \%$, and there is an increase in revenue. However, the precise herbicide application method is characterized by the higher cost of the sprayer. However, as our analyses show, with large cultivation areas the costs are reduced.

Less herbicide accumulates in the crop plant. This reduces the adverse effects of phytotoxicity, especially in the early stages of plant growth. Using less herbicide also benefits the environment. Less substances seep into the groundwater.

Sahoo et al. [34] conducted comparative studies of the impact of weed control methods on onion yielding. In their experiment, the cultivation technology, fertilization and protection were the same for all objects, and the weeding method was the differentiating factor. In experiments carried out during two growing seasons with the use of random complete blocks, the yield obtained from objects completely free of weeds was more than twice as high as from the control objects that were not weeded. The average weight of onions from non-weeded objects accounted for about $50 \%$ of the average weight of onions from objects completely free of weeds. A similar correlation between the average weight of onions and the presence of weeds on the plantation is confirmed by the conducted experiment, where there are statistically significant differences in this respect. Additionally, the experiment conducted in Polish conditions confirmed the best yielding of onions in plots that were systematically manually weeded. The experiment was conducted by the method of random blocks in four repetitions on plots with an area of $12.15 \mathrm{~m}^{2}$ by Kohut et al. [4] in 2010-2012, and it showed that the highest total yield (461.1 kg.100 m-2) and commercial yield $\left(448.3 \mathrm{~kg} \cdot 100 \mathrm{~m}^{-2}\right)$ came from these plots. The strong weed infestation of control objects caused an average soil coverage of $61 \%$ and it was higher than in our research, where it was $51 \%$.

The precise application of herbicides was possible due to running the working unit with high accuracy and separating the working liquid area from the crop and the areas that were not the purpose of application.

The factor that has a negative impact on the precision of application is the spray liquid drift. A small wind with a speed of $1-2 \mathrm{~m} \cdot \mathrm{s}^{-1}$ is beneficial from the point of view of crop penetration; however, it causes the risk of the spray liquid drifting to neighboring plants, reducing the retention of spray liquid on the weed surface. The usefulness of using such a solution was confirmed in the research by Roten et al. [35] and Foster et al. [36]. They showed that the use of low-drift nozzles alone resulted in a reduction in drift in the range of $81 \%$ to $94 \%$ compared to control (standard) sprayers. However, even better results were obtained with the use of low-drift nozzles in hood shields, where drift was limited from $95 \%$ to $99 \%$. Similarly favorable results were obtained thanks to the use of herbicide shields when spraying with fine and medium drops. The drift reduction was 
of $86 \%$ and $56 \%$ compared to conventional spraying without shields, measuring to $31 \mathrm{~m}$ with wind. At distances from 43 to $104 \mathrm{~m}$ with wind, the drift of liquids from sprayers with shields was lower than from open sprayers by about $50 \%$, regardless of the drop size used (fine, medium, very thick or ultrathick). Comparative studies were conducted in field conditions in an unshielded area with a working liquid containing herbicides in order to reflect the conditions occurring during spraying. Analysis carried out by these researchers suggests that the precise application of herbicides is possible when using shields, ensuring cooperation with the appropriate type of nozzle.

Comparative studies of traditional technologies with newly developed solutions allow the evaluation of their effectiveness and the setting of development directions. Precise positioning systems are one of the most commonly used tools. In the experiment, precise positioning allowed for automatic driving of the tractor with the sprayer prototype and the precise application of herbicides omitting the crops. Gidea [37], in his research, used the precise positioning data in a slightly different way. Searching for other effective methods different than the full-area conventional herbicide application, he used precise GPS RTK correction data to create a map of weed infestation in onion cultivation. The range of weed control was lower for precise, local application of herbicides compared to uniform application to the entire surface. The herbicide surface working area was reduced by $31.7 \%$ compared to conventional full-area application, which reduced the amount of used herbicides by $31.7 \%$.

In our research, the tractor was equipped with an automatic steering system with an accuracy of $2 \mathrm{~cm}$ with RTK NET signal correction. This system made driving the tractor and moving herbicide shields near the plants much easier.

Achieving yield at a satisfactory level with proper weed control and a reduction in herbicide consumption is the subject of many studies. Main et al. [5] conducted studies in the years 2008-2009 in a split-block system. In eight blocks there were 12 combinations of weed control, and six control objects occurred in four repetitions and in two sowing dates.

An experiment conducted in 2009 and 2010 by Pacanoski et al. [38] assessed the effect of herbicides and their mixtures on carrot yield in Macedonia. The experiment was conducted using random complete blocks in four repetitions. The plot area in the experiment was $20 \mathrm{~m}^{2}$. In the course of the experiment, the results were compared from plots treated with herbicides and their mixtures and the control plots, which were not weeded, and the plots that were weeded manually. Echinochloa crus-galli was one of the most dominant weeds in the experiment. The percentage of yield loss recorded in the experiment was estimated on the basis of the comparison of yield from control objects (without weeding) with plots weeded manually, and in the first year of the experiment it amounted to $58 \%$ and in the second year it was $66 \%$. In the experiment, no damage to the carrot plants, which may result from the application of herbicides, was observed. None of the used herbicides significantly reduced carrot yield.

The assessment of the effectiveness of various physical methods in weed control was carried out in the research in 2015-2016 by Anyszka and Golian [39]. The experiment was carried out in the cultivation of carrots in a "flat" manner with a row spacing of $45 \mathrm{~cm}$ in a set of random complete blocks in four repetitions. The plot area in the experiment was $12.2 \mathrm{~m}^{2}$. A gas burner, mechanical hoes and manual weeding were used to control weeds. There were also control plots left without weeding. Statistically, the highest yield was obtained from plots weeded manually. Different combinations of burning and mechanical weeding and hoeing gave lower yields, but not statistically different. The use of the burner alone resulted in a statistically lower yield than in the case of various firing combinations and other methods. The lowest statistical yield was obtained from control objects.

Therefore, one of the main goals has become the design and implementation of herbicide shields with the desired parameters. The sprayer that produces an even flat stream with an application angle of $95^{\circ}$ was chosen as the most optional for conducting the research. The designed shield takes into account the spray range and the required spraying width. When designing it, it was necessary to take into account that during work it will 
move about $2-4 \mathrm{~cm}$ above the ground level (to prevent hitting larger clods and stones). During design works, the possibility of its extension by means of flexible material without interfering with the structure was also taken into account.

\section{Conclusions}

The conducted research, analysis and verification of the developed technology of the precise application of herbicides in different systems of onion cultivation allowed us to formulate the following conclusions:

1. The developed technology allows a reduction in herbicide consumption in onion cultivation by $26 \%$ compared to conventional technology, which is of great importance in the aspect of introducing chemical substances into the environment and their accumulation in crops.

2. Empirical verification of the effectiveness of the developed technology, confirmed by statistical analyses of the obtained results, allows for an equivalent assessment of this method with the conventional method of the application of herbicides used in the study. Both total and commercial yield and the quality resulting from the average weight of onions in both methods do not differ statistically.

3. In the conducted research, no phytotoxicity of herbicides in relation to onions was reported, which results from the lack of statistical differences in the yield between the weed control methods used. This fact was also not noted during the assessment of plants on the objects.

4. Weed control in onion cultivation should be carried out by integrated methods, including the use of herbicides, but with their maximum reduction.

5. In further studies, attention should be paid to the potential danger of the condensation of the working liquid on the inner surface of the shield and the falling of drops into the onion root system.

Author Contributions: Conceptualization: P.P., A.O.; methodology: P.P., A.O.; software: P.R., R.W.; validation: P.R., R.W.; formal analysis: A.O., E.O.; investigation: I.K., A.O.; resources: A.O., P.R.; data curation: I.K., P.P.; writing—original draft preparation: P.R., A.O.; writing—review and editing: P.R., P.P., A.B.; visualization: A.O., E.O.; supervision: P.R.; project administration: E.O.; All authors have read and agreed to the published version of the manuscript.

Funding: The publication was co-financed within the framework of the Ministry of Science and Higher Education programme as "Regional Initiative Excellence" in years 2019-2022, Project No. 005/RID/2018/19.

Conflicts of Interest: The authors declare no conflict of interest.

\section{References}

1. Tona, E.; Calcante, A.; Oberti, R. The profitability of precision spraying on specialty crops: A technical-economic analysis of protection equipment at increasing technological levels. Precis. Agric. 2017, 19, 606-629. [CrossRef]

2. Campos, J.; Llop, J.; Gallart, M.; García-Ruiz, F.; Gras, A.; Salcedo, R.; Gil, E. Development of canopy vigour maps using UAV for site-specific management during vineyard spraying process. Precis. Agric. 2019, 20, 1136-1156. [CrossRef]

3. Gehrke, V.; Fipke, M.; Avila, L.; Camargo, E. Understanding the Opportunities to Mitigate Carryover of Imidazolinone Herbicides in Lowland Rice. Agriculture 2021, 11, 299. [CrossRef]

4. Andert, S. The Method and Timing of Weed Control Affect the Productivity of Intercropped Maize (Zea mays L.) and Bean (Phaseolus vulgaris L.). Agriculture 2021, 11, 380. [CrossRef]

5. Main, D.C.; Sanderson, K.R.; Fillmore, S.A.E.; Ivany, J.A. Comparison of synthetic and organic herbicides applied banded for weed control in carrots (Daucus carota L.). Can. J. Plant. Sci. 2013, 5, 857-861. [CrossRef]

6. Oliver, D.P.; Anderson, J.S.; Davis, A.; Lewis, S.; Brodie, J.; Kookana, R. Banded applications are highly effective in minimising herbicide migration from furrow-irrigated sugar cane. Sci. Total Environ. 2014, 466, 841-848. [CrossRef]

7. Song, J.-S.; Chung, J.-H.; Lee, K.; Kwon, J.; Kim, J.-W.; Im, J.-H.; Kim, D.-S. Herbicide-Based Weed Management for Soybean Production in the Far Eastern Region of Russia. Agronomy 2020, 10, 1823. [CrossRef]

8. Osuch, A.; Przygodziński, P.; Rybacki, P.; Osuch, E.; Kowalik, I.; Piechnik, L.; Przygodziński, A.; Herkowiak, M. Analysis of the Effectiveness of Shielded Band Spraying in Weed Control in Field Crops. Agronomy 2020, 10, 475. [CrossRef] 
9. Jiménez-Martínez, M.; Farjas-Abadia, M.; Quesada-Olmo, N. An Approach to Improving GNSS Positioning Accuracy Using Several GNSS Devices. Remote Sens. 2021, 13, 1149. [CrossRef]

10. Carballido, J.; Rodriguez-Lizana, A.; Aguera, J.; Perez-Ruiz, M. Field sprayer for inter- and intra-row weed control: Performance and labor savings. Span. J. Agric. Res. 2013, 11, 642-651. [CrossRef]

11. Perez-Ruiz, M.; Carballido, J.; Aguera, J.; Rodriguez-Lizana, A. Development and Evaluation of a Combined Cultivator and Band Sprayer with a Row-Centering RTK-GPS Guidance System. Sensors 2013, 13, 3313-3330. [CrossRef]

12. Serim, A.T.; Asav, U.; Turkseven, S.G.; Dursun, E. Banded herbicide application in a conventional sunflower production system. Turk. J. Agric. For. 2018, 42, 354-363.

13. Hunt, J. The Flagship of the Sugarcane Industry; Australian Canegrowers: Brisbane, Australia, 2013; pp. 12-20.

14. Centner, T.J.; Russell, L.; Mays, M. Vieving evidence of harm accopmanying uses of glyphosate-based herbicides under US legal requirements. Sci. Total Environ. 2019, 648, 609-617. [CrossRef]

15. Van Bruggen, A.H.C.; He, M.M.; Shin, K.; Mai, V.; Jeong, K.C.; Finckh, M.R.; Morris, J.G. Environmental and health effects of the herbicide glyphosate. Sci. Total Environ. 2018, 616, 255-268. [CrossRef] [PubMed]

16. Foster, H.C.; Reynolds, D.B.; Kruger, G.R.; Claussen, S. The effect of a shielded boom on of-target movement of various size spray droplets. In Proceedings of the Southern Weed Science Society 70th Annual Meeting, Birmingham, UK, 23-26 January 2017; p. 175.

17. Clayton, J. The Varidome precision band sprayer for row crops. International Advances in Pesticide Application. Asp. Appl. Biol. 2014, 122, 55-62.

18. Bjørnsson, O.H.; Maargaard, J.; Terp, C.I.; Wiggers, S.L. Dynamic Analysis of the Intelligent Sprayer Boom. In Proceedings of the 11th International Conference on Vibration Problems, Lisbon, Portugal, 9-12 September 2013.

19. Deprez, K.; Anthonis, J.; Ramon, H.; Van Brussel, H. Development of a Slow Active Suspension for Stabilizing the Roll of Spray Booms, Part 1: Controller Design. Biosyst. Eng. 2002, 81, 273-279. [CrossRef]

20. Fontanelli, M.; Frasconi, C.; Martelloni, L.; Pirchio, M.; Raffaelli, M.; Peruzzi, A. Innovative Strategies and Machines for Physical Weed Control in Organic and Integrated Vegetable Crops. Chem. Eng. Trans. 2015, 44, 211-216.

21. Fontanelli, M.; Martelloni, L.; Raffaelli, M.; Frasconi, C.; Ginanni, M.; Peruzzi, A. Weed Management in Autumn Fresh Market Spinach: A Nonchemical Alternative. Horttechnology 2015, 25, 177-184. [CrossRef]

22. Ikeda, I.; Kinoshita, T.; Yamamoto, T.; Yamasaki, A. Sowing time and temperature influence bulb development in spring-sown onion (Allium cepa L.). Sci. Hortic. 2019, 244, 242-248. [CrossRef]

23. Jeon, H.Y.; Womac, A.R.; Gunn, J. Sprayer boom dynamic effects on application uniformity. Trans. ASAE 2004, 47, 647-658 [CrossRef]

24. Lardoux, Y.; Sinfort, C.; Enfalt, P.; Sevila, F. Test Method for Boom Suspension Influence on Spray Distribution, Part I: Experimental Study of Pesticide Application under a Moving Boom. Biosyst. Eng. 2007, 96, 29-39. [CrossRef]

25. Sharda, A.; Fulton, J.P.; McDonald, T.P. Impact of response characteristics of an agricultural sprayer control system on nozzle flow stabilization under simulated field scenarios. Comput. Electron. Agric. 2015, 112, 139-148. [CrossRef]

26. Sobotka, S.M.; Lipiński, A.J. A New Structure of the Stabilization System of a Suspended. Agric. Eng. 2015, 1, 127-132.

27. Luck, J.D.; Zandonadi, R.S.; Luck, B.D.; Shearer, S.A. Reducing pesticide over-application with map-based automatic boom section control on agricultural sprayers. Trans. ASABE 2010, 53, 685-690. [CrossRef]

28. Melander, B.; Lattanzi, B. Pannacci, E. Intelligent versus non-intelligent mechanical intra-row weed control in transplanted onion and cabbage. Crop. Prot. 2015, 72, 1-8. [CrossRef]

29. Partel, V.; Kakarla, S.C.; Ampatzidis, Y. Development and evaluation of a low-cost and smart technology for precision weed management utilizing artificial intelligence. Comput. Electron. Agric. 2019, 157, 339-350. [CrossRef]

30. Gegner-Kazmierczak, S.; Hatterman-Valenti, H. Strip Tillage and Early-Season Broadleaf Weed Control in Seeded Onion (Allium сера). Agriculture 2016, 6, 11. [CrossRef]

31. Dammer, K.H. Real-time variable-rate herbicide application for weed control in carrots. Weed Res. 2016, 56, 237-246. [CrossRef]

32. Rahman, K.; Rahman, H.; Iqbal, M.; Ullah, K.; Khan, M.A.; Sadiq, M. Impact of manual weeding interval on onion (Allium cepa l.) yield and yield components. Pak. J. Weed Sci. Res. 2011, 17, 277-283.

33. Kalhapure, A.H.; Shete, B.T. Integrated weed management in onion. Indian J. Weed Sci. 2012, 44, 88-91.

34. Sahoo, S.K.; Charkavorty, S.; Soren, L.; Mishra, C.; Sahoo, B.B. Effect of weed management on growth and yield of onion (Allium cepa L.). J. Crop. Weed 2017, 13, 208-211.

35. Roten, R.L.; Ferguson, J.C.; Hewitt, A.J. Drift reducing potential of low drift nozzles with the use of spray-hoods. N. Z. Plant. Prot. 2017, 67, 274-277.

36. Foster, C.H.; Sperry, B.P.; Reynolds, D.B.; Kruger, G.R.; Clause, S. Reducing Herbicide Particle Drift: Effect of Hooded Sprayer and Spray Quality. Weed Technol. 2018, 32, 714-721. [CrossRef]

37. Gidea, M. The Differentiated Weed Control Methods in Onion Crops on the Cambic Chernozem in South Romania. J. Proc. Rom. Acad. 2014, 16, 49-53.

38. Pacanoski, Z.; Tyr, S.; Veres, T. Herbologia, Effects of Herbicides and Their Combinations in Carrots. Prod. Reg. Repub. Maced. 2014, 14, 47-60.

39. Anyszka, Z.; Golian, J. The effect of Flaming and Mechanical Treatments on Weed Control, Growth and Yield of Carrot. J. Res. Appl. Agric. Eng. 2017, 62, 7-12. 